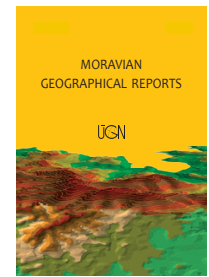

MORAVIAN GEOGRAPHICAL REPORTS

\title{
The spatial concentration of immigrant pupils at primary and lower secondary schools in the Czech Republic
}

\author{
Jiří HASMAN ${ }^{a}$, Yvona KOSTELECKÁ ${ }^{b}$, David HÁNA ${ }^{\text {* }}$
}

\begin{abstract}
Since the fall of the Iron Curtain and especially since joining the European Union, the Czech Republic has become a country with a sharply growing number of immigrants, who more and more often are coming to the country with the purpose of settling long term and starting a family. This change places demands on society as a whole but also on particular areas such as the education system, which needs to integrate these children successfully and ensure that they are provided with quality education. The experiences of countries with a long history of migration have shown a negative correlation between the extent of concentration of non-citizen pupils in a school and their academic performance. Such a relationship is explored in this article which examines the degree of concentration of non-citizen pupils at Czech primary and lower secondary schools both in terms of concentration in individual regions, as the spatial distribution of immigrants tends to be very unequal, and in terms of concentrations at particular schools within individual regions. The article shows that despite a current growing concentration of non-citizen students in some regions, there is not clear evidence to confirm a growing segregation at particular schools.
\end{abstract}

Keywords: spatial concentration; immigrants; primary and lower secondary schools; Czech Republic.

Article history: Received 10 December 2015; Accepted 18 July 2016; Published 31 December 2016

\section{Introduction}

Migration has always been a natural part of the lives of humans. In the history of humankind, individuals, groups, and whole nations have migrated for various reasons. Never, however, have so many people lived outside the land of their birth as they do now. Today, migration is a major, worldwide phenomenon. International data from 2013 published in the UN's International Migration Report (UN, 2013) indicate that between 1990 and 2013 the number of migrants ${ }^{1}$ rose from 155 million to 232 million, which is an increase of almost $50 \%$.

Large migrant populations place demands on the countries affected by emigration, which have to cope with the losses to their skilled labour force, and on host societies as well, as migration impacts their social climate and their political, cultural, and demographic conditions. It is therefore no surprise that countries adopt various measures in efforts to minimise the potential negative impacts of migration and strengthen its positive aspects. The success of migration is influenced by a variety of factors. One of the important factors is the historical experience individual countries have with migration, which is reflected in particular migration policies and oftentimes, also in the degree of acceptance with which migrants are received by the host society.

Different countries have had a variety of different historical experiences with migration. In the history of some countries (for example the United States, Canada and Australia), migration has played an important role both in shaping the modern face of those nations and later in their continued development (Freeman, 1995), and in reinforcing their position in the world system (Wallerstein, 1974). Other countries have had different experiences. For example, for several centuries Western European states were sources of migration and gained experience with immigration much later. They became destinations for mass migrations after the Second World

\footnotetext{
${ }^{a}$ Department of Social Geography and Regional Development, Faculty of Science, Charles University in Prague, Czech Republic

${ }^{b}$ Institute for Professional Development, Faculty of Education, Charles University in Prague, Czech Republic, (*corresponding author: D. Hána, e-mail: david.hana@pedf.cuni.cz)
}

\footnotetext{
${ }^{1}$ According to the UN (2013) report, a migrant is a person who was born in a country other than the one he/she lives in or has the status of foreign national in the country he/she lives in.
} 
War when less skilled immigrants, mostly from less advanced European states and former colonies, began arriving in these countries (Freeman, 1995) to saturate a demand for labour during the post-war economic boom.

The Czech Republic, like other states in what is referred to as the New Europe, has a very different migration history. In modern history, these countries went through a long period of stagnation owing to the political situation. After the fall of the Iron Curtain, these countries passed through a period of economic and political transformation followed by relatively rapid economic growth. These recent developments, together with these countries' accession to the European Union, increased their appeal and helped turn them into new destinations of immigration. With this they entered a new period in their history, acquiring their own particular experience with migration. In connection with the growing number of immigrants, the issue of integration has become a political priority. Expert studies on this issue are thus a valuable source of information and material for actors at various decision-making levels, ranging from teachers, employees in state administrations and to politicians. In Western countries extensive research has been systematically devoted to this subject for more than half a century and has been presented in an equally extensive body of expert literature (e.g. Alba and Nee, 2005; Foner and Alba, 2008; Massey, 2008; Portes et al., 2005; Schneeweis, 2011, 2013, 2015; Zhou and Cai, 2008). This is the result of the lengthy experience other countries have with migration and the conviction that a successful migration policy has a crucial impact on various spheres of society, as well as a fundamental influence on the sociopolitical climate in the country. In the Czech Republic, where higher rates of immigration only began to be registered in the 1990 s and especially after 2004 , the literature on this phenomenon and its impact on individuals and society has been expanding rapidly in recent years (Drbohlav, 2011; Drbohlav et al., 2007, 2010; Drbohlav and Uherek, 2007; Janská, 2007; Lachmanová, 2007; Novotný et al., 2007; Papoušková, 2007).

Given the relatively short period of time during which migration has been the subject of research in the Czech Republic, it is clear that it has not yet been possible to sufficiently cover every aspect of the process of integrating migrants into the host society and to the extent that the subject warrants. One relatively overlooked area of research is the integration of non-citizen pupils into the education system. Many studies on the integration of non-citizen pupils focus on the development of communication skills in the Czech language (e.g. Hájková, 2014, 2015; Jančařík and Kostelecká, 2015; Kostelecká et al., 2013, 2014, 2015; Vodičková and Kostelecká, 2014, 2016) and the integration of students in the classroom (Braun et al., 2015), among others.

There are however no studies on the concentration of non-citizen pupils in schools, a topic frequently discussed in the international literature (Cebolla-Boado and Garrido-Medina, 2011; Gorad, 2009; Johnston et al., 2008; Pedraja-Chaparro et al., 2016; Ruoff, 2006; Schneeweis, 2011, 2013, 2015). The experiences of countries with a long history of migration have shown a negative relationship between the extent of concentration of non-citizen pupils in a school and their academic performance (e.g. Schneeweis, 2013). To study this topic in the Czech context should be of great interest as the situation in the Czech Republic is somewhat specific. Unlike in most advanced countries, parents have the right to choose what school their children attend irrespective of their place of residence - as long as the school of choice has sufficient capacity ${ }^{2}$. By their choices, then, parents can affect significantly the degree of concentration of non-citizen pupils at schools, potentially contributing to the segregation of migrants.

This article has three main goals:

1. The first is to analyse the spatial distribution of noncitizen pupils in the Czech Republic and to examine how this situation has evolved over time. The spatial distribution of pupils, both relevant groups of noncitizens by country of origin and non-citizens in total, will be examined at various spatial levels in order to reveal and to describe its main characteristics. This will set the stage for the second goal;

2. The second goal is to determine the degree of concentration of non-citizen pupils at individual schools and to identify how it has changed over time. The key questions are whether the increasing number of noncitizen pupils in the Czech school system is leading to their growing concentration in specific schools, and whether this eventual growth is mainly due to changes in their spatial concentration, or to other factors such as parental choice of school within a geographical region. Another important question is whether a tendency can be observed at some schools to specialise in the integration of pupils from certain source countries. The existence of such schools may serve as an identifier of the process of segregation of different ethnic groups from each other, which may be considered a 'risk factor' in the process of integration; and

3. Finally, the third goal is to verify the observations made at larger geographical scales by carrying out case studies of selected towns (Říčany, Mladá Boleslav, Karlovy Vary, Teplice, Tachov) and two boroughs in Prague (Prague 13 and 14). These case studies should allow us to analyse in detail the changing ethnic composition of individual schools in selected types of neighbourhoods, and thereby to observe the effects of the spatial concentration of non-citizens, parental choice, and Tiebout sorting.

\section{The Czech Republic as a new immigration country}

Among the countries of the New Europe, the Czech Republic occupies an exceptional position as it is the most attractive destination for migration in this region (Čermák and Janská, 2011; Drbohlav, 2011). In the past the situation was different. Even though the country was throughout its history a multi-ethnic area with a large German-speaking population, in the post-war period (following the expulsion of the Sudeten Germans) the situation changed dramatically and it became an ethnically almost homogeneous country. Although net migration in the Czech part of Czechoslovakia was positive after World War II, the total number of immigrants was very low (ČSÚ, 2012a). After the Velvet Revolution in 1989, political circumstances changed dramatically. As a consequence, amendments were gradually made to the state's migration policy which supported

\footnotetext{
${ }^{2}$ Schools are obliged to give priority to enrolling students from their own district.
} 
immigration and led to an increase in the number of migrants who were attracted by the rapidly growing economy. The main increase occurred after 2004 when the Czech Republic joined the European Union. While in 2003 there were only 240,000 non-citizens registered as residing in the Czech Republic, in 2008 there were 438,000 non-citizens in the country. There are currently about 465,000 noncitizens in the Czech Republic (ČSÚ, 2015a), which is equal to approximately $4.5 \%$ of the population. But it is not the number of non-citizens alone that is increasing but also the number that plan to settle permanently, start a family, and raise children in the Czech Republic. The country is becoming a destination for migration. It must nevertheless be pointed out that despite the changes and relatively sharp rise in the number of non-citizens in the country in recent decades, the share of non-citizens in the Czech Republic is still below the EU average.

There are several aspects of migration to the Czech Republic which should be mentioned:

- Economic factors play a major role in encouraging immigration to the Czech Republic, especially the structure of the economy and the availability of jobs. This is because economic labour migration is the dominant form of immigration (Čermák and Janská, 2011; Drbohlav, 2011; Janská et al., 2014).

- Unlike most European countries, the majority of noncitizens in the Czech Republic come from a limited number of countries - non-citizens from the four largest groups altogether make up almost $65 \%$ of the total number of non-citizens. Most immigrants come from Ukraine $(106,000)$, Slovakia $(102,000)$, Vietnam $(57,000)$ and Russia (57,000).

- The nationality and ethnic composition of non-citizens in the Czech Republic reflects the country's specific history and the linguistic proximity between Czech and the languages of some source countries. Ukrainians, Slovaks, Russians and Poles come from Slavic-speaking post-socialist countries, while the substantial amount of immigration from Vietnam follows from a past wave of labour migration in the 1980 s that occurred on the basis of bilateral international agreements at that time (Drbohlav, 2011; Janská et al., 2014).

- The age structure of non-citizens in the Czech Republic is distinct from that of the majority population. There is a larger share (almost 40\%) of young people in the 25-39 productive age group among non-citizens (ČSÚ, 2014a), in contrast to one-quarter of the majority population (ČSÚ, 2014b). Despite this, there is also a smaller share of children in the non-citizen population (4.5\% compared to $3.2 \%$ in the case of majority population: ČSÚ, 2014a), which is in contrast to the situation in most Western countries. The most likely reason for this situation is the different structure of source countries. While quite a large share of immigrants to Western countries comes from developing countries with high fertility, a significant proportion of Czech immigrants come from Eastern Europe, which is a region with extremely low fertility. This (and the fact that their motives for migration to the Czech Republic are primarily economic) means that they have relatively few children, especially in the case of Ukrainians and Slovaks. In contrast, the highest numbers of children born to non-citizens in the Czech Republic are born to Vietnamese parents intending to settle long term in the country and to start a family (Kostelecká et al., 2015).
- A final important factor is the spatial behaviour of noncitizens in the Czech Republic. Immigrants tend to settle in cities and their suburbs, especially in the metropolitan area of Prague, where approximately one-third of all foreign nationals live. Popular immigrant destinations are towns that have successful industrial enterprises, as well as the border region with neighbouring Germany. Despite this, some of the phenomena that have been witnessed abroad as commonly accompanying immigration have not been observed. Most notably this refers to the tendency towards residential segregation of immigrants in urban areas and the formation of large ethnic neighbourhoods. These phenomena are far less apparent in the Czech Republic than they are in Western European countries (for example Drbohlav, 2011).

\section{Concentrated populations of non-citizen pupils at particular schools: A factor in the integration process}

Given the generally increasing migration rates, scholars and experts have directed their attention to identifying the factors that encourage successful integration, and understanding and explaining why the integration process is more successful among some individuals and groups than others. The potential and the risks that come with migration also vary widely depending on different spatial factors. Many studies have shown that the environment in which people live has an effect on a variety of different aspects of their lives, including their academic performance and educational attainment, social behaviours, health, work, and social mobility (see, e.g. Durlauf, 2005, Galster, 2012; van Ham and Manley, 2012a, 2012b, 2013).

A similar discussion is also underway in the field of education. The question is to what extent the degree of concentration of non-citizen students in schools affects their academic performances and thereby the entire process of integration. Some studies show a negative correlation between the level of concentration of noncitizen students in a school and their academic performance (e.g. Schneeweis, 2013; Pedraja-Chaparro et al., 2016). Analysing the situation in Vienna between 1980 and 2001, Schneeweis (2013) concluded that a larger concentration of minorities in a school has a negative impact on the academic performance of those minority students. This is especially true when the immigrants concentrated in a school are from the same ethnic background. Schneeweis did not demonstrate, however, that a large concentration of immigrant children in a school negatively impacts the performance of students from the majority population. Similarly, Pedraja-Chaparro et al. (2016), studying the situation in Spain, found a negative correlation between the share of immigrants in a school and their academic performance. They also discovered, however, that if the share of immigrant students is more than $15 \%$, the performance of the other students from majority backgrounds is also negatively affected. Concerns about the potential negative effects of large concentrations of immigrant students led many advanced countries with large immigrant populations to try to develop an educational system that would prevent the emergence of schools with very high proportions of immigrant students.

Fulfilling this idea at the elementary level of the education system, however, may be constrained by two fundamental factors: the composition of the population 
(ethnic, cultural and social) in the locality of the school, and whether or not school choice is an option in the society. While the education system can have only an indirect and limited influence on the composition of the population in a school district ${ }^{3}$, school choice at the primary school level is directly defined in the education laws of individual countries ${ }^{4}$. In theory, the right to choose schools can either support integration or increase segregation (Riedel et al., 2010). Current studies nevertheless indicate that in practice school choice tends to have the effect of increasing the social and ethnic segregation of primary school pupils (Burgess and Briggs, 2006; Riedel et al., 2010).

One reason that this occurs is that when the school choice option is open to parents they prefer those educational opportunities that seem to be the most efficient, the aim being to obtain the best educational outcome for lower costs. The costs of the school choice option can be represented by tuition and travel expenses (Riedel et al., 2010), while its possible benefits are usually seen as the possibility to choose the socio-economic and ethnic composition of the school population, a good educational environment in the school, the similarity between the norms and values of the school and those of the family, and the school with an overall better performance of pupils (see, e.g. Riedel et al., 2010). It is apparent, moreover, that some of these benefits are linked to others. For example, schools with a large share of pupils from socially and economically advantaged backgrounds usually have better overall outcomes and fewer disciplinary/behavioural problems among pupils and attract talented and motivated pupils (see, e.g. Opdenakker and van Damme, 2001; Thrupp and Lupton, 2006). Parents then also naturally tend to avoid schools with a large percentage of pupils from disadvantaged backgrounds (Rieder et al., 2010). Black (1999) has shown that in some cases parents are even willing to pay higher rents in order to live in a locality where the school boasts better results among its pupils. Choosing schools is more important for parents from a higher socio-economic background (see, e.g. Bourdieu, 1983). Their economic, social and cultural capital gives them more opportunities to choose the 'right' schools than parents with lower incomes, who tend to favour schools that are in the proximity of their homes in order to minimise transportation costs (Riedel et al., 2010). These parents also tend to place less emphasis on the school's academic standards (Hastings et al., 2006).

Some scholars believe that differences in the composition of the student populations at public schools are not just the result of the social and ethnic composition of a neighbourhood and parental choices, but also of the number of school districts that exist in a locality. More accessible school districts tend to lead to a more homogeneous school population in a given district. The literature often describes this as the 'Tiebout model' or 'Tiebout sorting', as explained, for example, in Urguiola (2005) and Riedel et al. (2010). This model is based on the principle that when the selection of services and public goods in a locality is sufficient enough for every individual to choose what suits her/him best, people then demonstrate their preferences for particular services and public goods in a manner that in the literature is referred to as 'voting with one's feet'. The advantage of this model is that it allows individual providers of public goods and services to compete with each other, and this can have a positive effect on the quality of public goods and services and the selection users have to choose from, so that each person can choose what suits her/him best. A constraint on how this model functions is peoples' willingness to move or to commute to obtain the goods and services they prefer, as well as a sufficient degree of knowledge about their quality.

These research studies show that in the international literature the spatial distribution of immigrants and their concentration in schools are issues that receive considerable attention because they are important factors in determining the successful integration of immigrants. For the present there is still a lack of Czech studies on the degree of concentration of non-citizen pupils in schools. This article seeks to fill in this gap and to explore the situation in the Czech Republic as one of the countries of the New Europe.

\section{The spatial distribution of non-citizen pupils at primary and lower secondary schools by country of origin}

\subsection{Methodology and delimitation of non-citizens' origins}

Before proceeding to analyse the concentration of non-citizen pupils ${ }^{5}$ at Czech primary and lower secondary schools ${ }^{6}$, it is first necessary to look at their spatial concentration at the level of the various types of territorial units in the country (regions, administrative districts of municipalities with extended powers, the boroughs of Prague). An analysis was conducted on data from the Ministry of Education, Youth and Sport (Statistical Yearbook on Education - Performance Indicators 2005/2006, 2007/2008, 2009/2010, 2011/2012, 2013/14).

Owing to the small numbers of non-citizen pupils from some groups enrolled in Czech schools, separate analyses of the spatial distributions were carried out only for the nine countries whose citizens represent the largest numbers of noncitizen pupils at these types of schools. The numbers of pupils from other countries were merged into macro-regional groups; countries analysed separately were not then included as parts of these groups (for example, data for post-Soviet countries do not include data for Russia, Ukraine, and Moldova). A complete list of the pupils' background countries and regions, including size of these groups is presented in Table 1. As

\footnotetext{
${ }^{3}$ In some countries people make their choices about where to live guided by the quality of schools in the locality. Significant differences in the quality of schools thus encourage residential segregation.

${ }^{4}$ In many advanced countries parents can only enrol their children in the primary school designated for their district (e.g. France, UK, Germany, the United States, etc.). The option of enrolling in some other school is limited to special cases.

${ }^{5}$ Non-citizens are defined as persons whose citizenship is other than Czech; individual immigrant groups are therefore defined as groups of students with the same citizenship. Data for some countries were missing from the database of the Ministry of Education, Youth and Sport; however, the only more significant gaps are for Serbia and Montenegro for the year 2005.

${ }^{6}$ School attendance in the Czech education system is compulsory for children between the ages of 6 and 15 and it has two stages: the five-year primary level (ISCED 1) and the four-year lower secondary level of education (ISCED 2); 11\% of children (who are defined as the most gifted) nonetheless pass through the lower secondary level at highly selective multi-year gymnasia or academies.
} 
one can see in the last two rows, the number of non-citizen pupils increased continuously due to constant immigration. In contrast, the number of native pupils steadily decreased at first and then slightly increased again; these trends were driven by the demographic situation in the Czech Republic.

\subsection{The basic parameters of the spatial distribution of non-citizen pupils}

In order to obtain basic information on the current spatial distribution of non-citizen pupils at primary and lower secondary schools, we analysed data for the years 2005 and 2013. Figure 1 shows the share of noncitizen pupils at all these schools in the given year for the level of the administrative districts of municipalities with extended powers (hereafter ADMEPs), which were used because in $\operatorname{size}^{7}$ and definition they best correspond to the country's natural geographical regions. The data indicate that the spatial distribution of non-citizen pupils replicates the migration trajectories of adult immigrants that have been described elsewhere in the Czech literature (Čermák and Janská, 2011; Drbohlav et al., 2010; Janská et al., 2014). This is logical because children of this age usually follow their parents ${ }^{8}$. It can thus be claimed that the spatial distribution of non-citizen pupils is determined by the spatial behaviour of their parents. The map shows the dominant position of Prague, as well as the 'West-East' gradient: the latter refers to the fact that the number of non-citizen pupils decreases the further east in the country one goes. Significantly larger shares are found in prospering industrial centres (e.g. Pilsen, Mladá Boleslav) and Brno, as well as in the metropolitan area of Prague.

If we compare the maps for both years, the largest increases in the share of non-citizen pupils were observed in the metropolitan area of Prague and in the development axis between the growing industrial centres of Pilsen, Mladá Boleslav (both with expanding transport industry) and Liberec. Nevertheless, the map also shows a slight tendency towards de-concentration as the share of noncitizen pupils slightly decreased in the most western regions and, conversely, there has been an increase in the territory of Moravia and in particular in the Brno agglomeration.

This basic picture of the spatial distribution of noncitizen pupils, however, does not tell us anything about the specific spatial behaviour of individual groups. It is well known that there are significant differences between immigrant groups in this respect (see, e.g. Hasman, 2014). Although it is beyond the scope of this paper to provide any

\begin{tabular}{|c|c|c|c|c|c|}
\hline Country of pupils' origin & 2005 & 2007 & 2009 & 2011 & 2013 \\
\hline Bulgaria & 126 & 145 & 208 & 257 & 337 \\
\hline China & 177 & 242 & 264 & 281 & 276 \\
\hline Moldova & 180 & 217 & 270 & 304 & 305 \\
\hline Mongolia & 291 & 347 & 445 & 457 & 350 \\
\hline Poland & 150 & 182 & 220 & 250 & 274 \\
\hline Russia & 940 & 905 & 1,161 & 1,244 & 1,263 \\
\hline Slovakia & 2,074 & 2,455 & 2,805 & 3,161 & 3,439 \\
\hline Ukraine & 2,708 & 2,957 & 3,170 & 3,392 & 3,589 \\
\hline Vietnam & 3,473 & 3,373 & 3,171 & 2,852 & 2,906 \\
\hline Other Asia & 62 & 129 & 132 & 144 & 172 \\
\hline Post-Soviet countries & 736 & 684 & 638 & 622 & 630 \\
\hline Northern Africa and the Middle East & 176 & 178 & 201 & 190 & 230 \\
\hline North America & 120 & 129 & 113 & 112 & 108 \\
\hline Sub-Saharan Africa & 55 & 45 & 48 & 45 & 47 \\
\hline Central and Eastern Europe & 471 & 590 & 614 & 622 & 722 \\
\hline Western Europe & 360 & 349 & 352 & 350 & 400 \\
\hline Latin America & 24 & 22 & 18 & 22 & 29 \\
\hline Oceania (incl. Australia) & 3 & 10 & 9 & 10 & 8 \\
\hline Total Immigrant population & 12,283 & 12,960 & 13,839 & 14,316 & 15,090 \\
\hline Czech Republic & 904,296 & 831,900 & 780,620 & 780,298 & 812,545 \\
\hline
\end{tabular}

Tab. 1: Countries of pupils' origin and the size of the individual groups in the analysis

Source: Authors' calculations based on data from the Ministry of Education, Youth and Sport (Statistical Yearbook on Education - Performance Indicators 2005/2006, 2007/2008, 2009/2010, 2011/2012, 2013/2014). The values show the numbers of pupils with citizenship from the given country (or region) in given year.

\footnotetext{
${ }^{7}$ Given the very small average size of Czech municipalities, the variation of indicators at this level would have been too large and the map would have looked like a complex mosaic. By contrast, a regional breakdown would have offered too little detail of the spatial patterns.

${ }^{8}$ An exception is represented by labour immigrants, who usually travel to the destination country without their children. In the Czech Republic this mainly applies to two groups: Ukrainians and Western Europeans. Because they both settle at a higher rate in Prague, the shares of pupils from these two country groups in Prague is much smaller than what would otherwise correspond to their population sizes.
} 


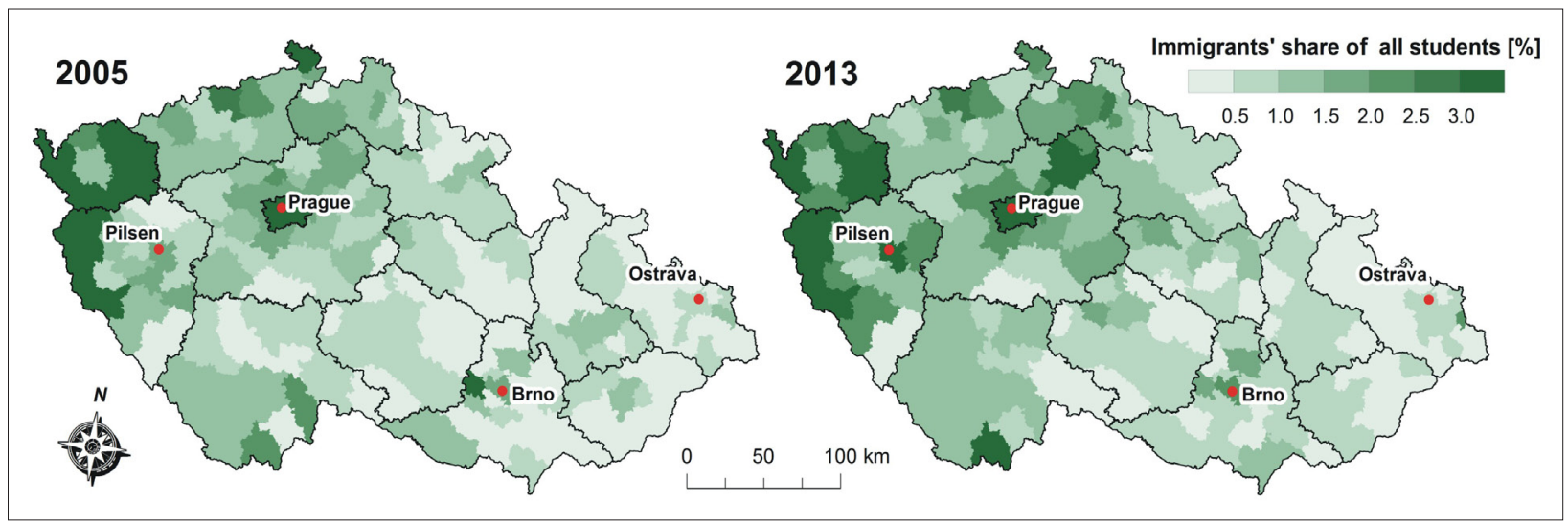

Fig. 1: The share of non-citizen pupils at primary and lower secondary schools in relation to the total number of pupils at the schools in ADMEPs in 2005 and 2013

Source: Authors' calculations based on data from the Ministry of Education, Youth and Sport (Statistical Yearbook on Education - Performance Indicators 2005/2006 and 2013/2014)

deeper analysis, we shall present at least the basic trends in the spatial distributions of individual immigrant groups between the 2005/2006 and 2013/2014 school years. Given that we are focusing mainly on the level of concentration, we calculated two indicators of the spatial concentration of individual groups during the period of observation. The results are presented in Figure 2: the $\mathrm{X}$ axis represents the percentage of pupils from the given group attending a school in Prague (as the key immigration city), and the $\mathrm{Y}$ axis is the Gini coefficient of concentration ${ }^{9}$, which indicates how evenly the given group is distributed across individual ADMEPs. Figure 2 confirms that there are large differences between individual groups in terms of the degree of spatial concentration. For example, the Gini coefficient of concentration in 2013 was 0.385 in the case of Slovak pupils, but more than 0.8 in the case of pupils from China or Sub-Saharan Africa. As one would expect, there is a positive linear relationship between the two indicators, which is particularly evident in the year 2013 (see the red squares). Some groups in this figure, however, lie outside the main (regression) axis. This is particularly the case for Mongols and Poles, which have relatively high Gini coefficients, but

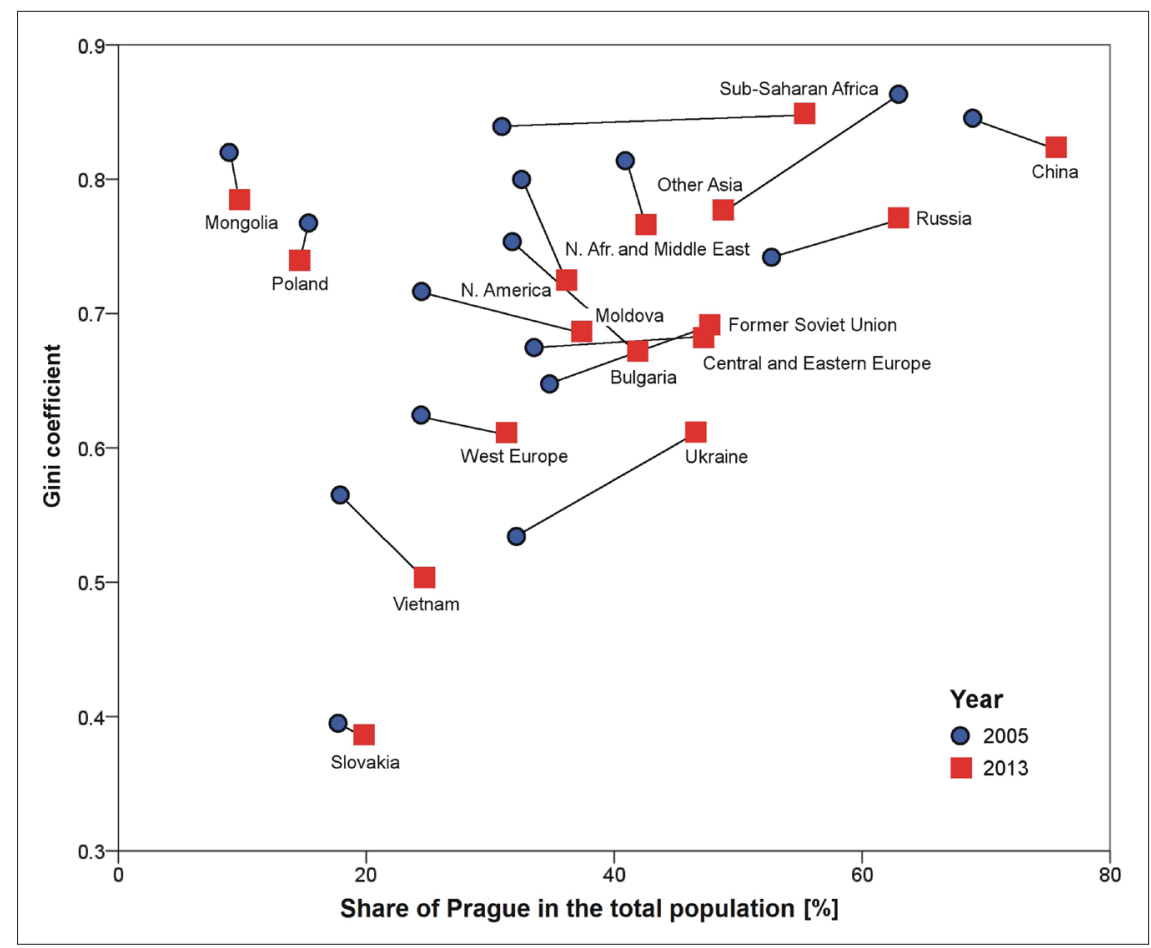

Fig. 2: The spatial concentration of non-citizen pupils between 2005 and 2013. Source: Authors' calculations based on data from the Ministry of Education, Youth and Sport (Statistical Yearbook on Education - Performance Indicators 2005/2006 and 2013/2014). Note: Groups from Oceania and Latin America are not shown owing to the very small number of pupils from these groups.

\footnotetext{
${ }^{9}$ The Gini coefficient of concentration has the range (0-1), where zero indicates the given phenomenon occurs evenly across all units, and one indicates that the phenomenon is concentrated in one unit. In the case of the student populations considered, a higher Gini coefficient of concentration indicates greater spatial concentration of non-citizen pupils at the level under analysis.
} 
their concentration with respect to Prague is relatively low, which indicates that these groups are concentrated, but elsewhere than in Prague.

If we look at spatial concentration over time, two contradictory phenomena can be observed among most groups: a decreasing Gini coefficient and a growing share of non-citizen pupils in Prague (Fig. 2). As our data show ${ }^{10}$, over the course of the period under observation most groups typically settled in Prague and then they began to settle in the suburbs around Prague (and Brno) or in the regions along the German border. A different trend, however, was observed among the groups from the former Soviet Union, the largest of which are the Ukrainians and Russians. Although these groups have also increased their representation in the Prague metropolitan area, they are much more concentrated directly to the capital city and, contrary to the other groups, their Gini coefficients increased (Fig. 2). Besides that, they established a secondary concentration in northwest Bohemia. By contrast the lowest level of concentration is observed among two specific groups: Slovaks and Vietnamese. For a long time Slovaks shared a state with the Czechs and the two groups are culturally very similar; therefore, their spatial behaviours are most like those of the domestic population. The Vietnamese community members largely work in retail trade networks and as a result they tend to settle in every region (Janská et al., 2014), but they favour regions close to the western border, which are frequently visited by the inhabitants of nearby wealthier states.

To conclude this section, the trends in the concentration of non-citizen pupils as a whole (Tab. 2) can be described. First, the lowest Gini coefficients are observed in the boroughs of Prague. This is consistent with the findings of Drbohlav (2011) that Prague, in this respect, differs from Western metropolitan areas where, by contrast, immigrants tend to settle much more in certain neighbourhoods ${ }^{11}$. Secondly, the Gini coefficient at every administrative level examined in this analysis increased during the period under observation, a finding that differs from preceding findings that showed declining concentrations of all groups defined by country of origin (Fig. 2). There are two possible explanations for this inconsistency:

1. Individual groups, as they grow in size, expand over time into multiple regions, but at the same time most groups have a tendency to spread to the same regions, where they may become increasingly concentrated.
This trend can be demonstrated by the example of the Poles: Gini coefficients for this group decreased at every administrative level, but at the same time the places of their concentration shifted considerably from the border regions, areas where there are not too many other noncitizens, primarily to Central Bohemia, region where there are concentrations of other groups. In this way, Polish pupils contributed to increasing the concentration of non-citizens in localities and schools already the most exposed to non-citizens; and

2. Although there was a spatial de-concentration of most groups, with the exception of the Slovaks (where the changes were minimal) and the Vietnamese, these groups represented only a small share of the total number of non-citizens. Conversely, a strong process of concentration occurred among Ukrainians and Russians (the first and fourth largest groups in 2013): the large share of Ukrainians and Russians among noncitizens explains why the Gini coefficients for the whole population of non-citizens in Table 2 increased, even if the Gini coefficients calculated separately for most groups decreased over the observed period (see Fig. 2).

\section{The concentration of non-citizen pupils at schools}

The analysis of the spatial distribution of non-citizen pupils in the Czech Republic completed, we now focus on determining the degree of their concentration at individual schools. The aim is to identify how the number of non-citizen pupils at schools has changed over time in relation to total student populations, and whether there is a tendency at any of the schools to specialise in the integration of pupils from particular source countries (a tendency that has been found in studies abroad, e.g. Riedel et al., 2010), or whether the schools tend to integrate pupils from every background.

For the initial analysis we again drew on data from the Ministry of Education, Youth and Sport (Statistical Yearbook on Education - Performance Indicators 2005/2006 and 2013/2014). Our analysis did not cover all schools, but only those in which some non-citizen pupils were enrolled during the period under observation. Figure 3 shows the statistical distribution of the share of non-citizen pupils at schools for the years 2005 and 2013. In both years the distribution was highly right skewed as most of the schools fall within the category in which non-citizen pupils make

\begin{tabular}{lrrrrrr}
\hline \multirow{2}{*}{ Administrative level } & \multirow{2}{*}{$\begin{array}{c}\text { Number } \\
\text { of units }\end{array}$} & \multicolumn{5}{c}{ Gini coefficient/Years } \\
\cline { 3 - 7 } & & 2005 & 2007 & 2009 & 2011 & 2013 \\
\hline Regions & 14 & 0.373 & 0.382 & 0.391 & 0.373 & 0.406 \\
ADMEPs & 206 & 0.456 & 0.462 & 0.463 & 0.463 & 0.471 \\
Boroughs of Prague & 22 & 0.156 & 0.141 & 0.164 & 0.160 & 0.164 \\
\hline
\end{tabular}

Tab. 2: Trends in the Gini coefficient for the concentration of non-citizen pupils at various administrative levels Source: Authors' calculations based on data from the Ministry of Education, Youth and Sport (Statistical Yearbook on Education - Performance Indicators 2005/2006, 2007/2008, 2009/2010, 2011/2012, 2013/2014)

Note: The data correspond to the values of the Gini coefficient measured at the territorial unit indicated in the first column

\footnotetext{
${ }^{10}$ Limited space sadly does not allow us to show maps for distinct migrant groups; however, the authors will provide these maps upon request.

${ }^{11}$ A direct comparison of the degree of spatial concentration between Prague and Western cities is however very difficult as this value is highly dependent on the scale of territorial units.
} 


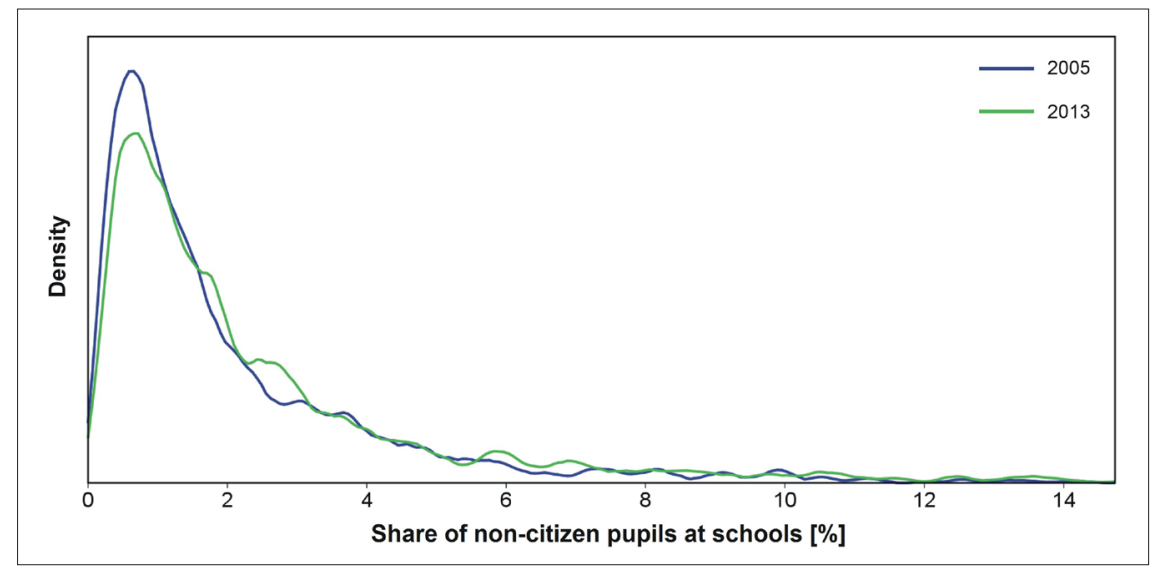

Fig. 3: The distribution of the share of non-citizen pupils as a percentage of all pupils at the Czech primary and lower secondary school in 2005 and 2013: kernel density estimates

Source: Authors' calculations based on data from the Ministry of Education, Youth and Sport (Statistical Yearbook on Education - Performance Indicators 2013/2014)

up $0.5-1 \%$ of all pupils (this is the case of more than onefifth of all schools $)^{12}$. The share of schools with a small percentage of non-citizen pupils, however, decreased between 2005 and 2013, while the number of schools with a large percentage of them increased. Moreover, the share of schools with at least one non-citizen pupil declined from $54.5 \%$ to $49.3 \%$, despite the fact that the number of such pupils increased between 2005 and 2013. This indicates that the concentration of non-citizen pupils at schools somewhat increased over the observed period.

The increased concentration of non-citizen pupils at schools may partly be the result of the growing spatial concentration of non-citizen pupils (see above). In order to test this, we conducted an analysis using a decomposition of the Theil index (for more, including the formula used, see Netrdová and Nosek, 2009; Novotný, 2007; Novotný et al., 2014). The Theil index is an index of concentration much like the Gini coefficient, but it has a major advantage: not only can it measure changes in the overall concentration of non-citizen pupils at schools $(0$ minimum concentration, ln $n$ maximum, where $n$ represents the total number of cases), but it can also be used to calculate to what extent differences between individual regions (in this case ADMEPs) contribute to this concentration and how much concentration there is within these regions (that is, non-spatial concentration at schools within individual ADMEPs, given by parental choice). Table 3 shows the results of this analysis. In the first row we can see that the overall level of concentration declined at first and then was steadily increasing over the observed period. The source of this increase is explained by the decomposition result: concentration within the regions decreased sharply between 2005 and 2007 from 0.327 to 0.298 , which explains the initial decline in overall concentration. After that the level of concentration within the regions remained almost without change, which means that the increase in overall concentration is due to changes in the spatial distribution of non-citizens and not to parental choice. As we can actually see in the third row, values of the between-regional component of the Theil index were continually increasing. This is not surprising and corresponds to the Gini coefficients in Table 2. To sum up, the results of the Theil decomposition show that the increase in the concentration of non-citizen pupils at schools apparent in Figure 3 is due to growing spatial (between-regional) concentration, not by the concentration of non-citizens to schools within the geographical regions.

We shall now try to determine whether non-citizen pupils at any given school tend to be mostly from the same migrant group or whether there is a variety of migrant groups at the school. Table 4 shows the number of different groups at a school (based on the division presented in Tab. 1) in relation to the percentage of all non-citizen pupils in school in 2005 and 2013. It is important to note that the schools

\begin{tabular}{lccccc}
\hline \multicolumn{1}{c}{ Year } & $\mathbf{2 0 0 5}$ & $\mathbf{2 0 0 7}$ & $\mathbf{2 0 0 9}$ & $\mathbf{2 0 1 1}$ & $\mathbf{2 0 1 3}$ \\
\hline Theil's coefficient - altogether & 0.471 & 0.449 & 0.462 & 0.474 & 0.485 \\
Inequality within ADMEPs & 0.327 & 0.298 & 0.294 & 0.295 & 0.300 \\
Inequality between ADMEPs & 0.143 & 0.152 & 0.168 & 0.178 & 0.184 \\
Inequality within ADMEPs $(\%)$ & 69.6 & 66.3 & 63.6 & 62.4 & 62.0 \\
\hline
\end{tabular}

Tab. 3: The concentration of non-citizen pupils at schools measured with the Theil index

Source: Authors' calculations using the EasyStat 1.0 program (Novotny et al., 2014) based on data from the Ministry of Education, Youth and Sport (Statistical Yearbook on Education - Performance Indicators 2005/2006, 2007/2008, 2009/2010, 2011/2012, 2013/14)

Note: The figures for both components are after deducting the stochastic component (see Novotny et al., 2014). The index was calculated from the shares of non-citizen pupils at schools weighted by school size

\footnotetext{
${ }^{12}$ It may be surprising to find that the share of schools on the left side of the distribution $(0-0.5 \%)$ is small. This is largely due to a mathematical distortion, however, as only schools with more than 200 pupils can have a share of non-citizen pupils less than $0.5 \%$, and naturally the number of such schools is limited.
} 


\begin{tabular}{ccccccccc}
\hline $\begin{array}{c}\text { Share of non-citizen pupils of the total } \\
\text { number of pupils at the school [\%] }\end{array}$ & \multicolumn{3}{c}{ Number of groups of non-citizen pupils at individual schools [\%] } \\
\cline { 2 - 9 } $\mathbf{2 0 0 5}$ & $\mathbf{1}$ & $\mathbf{2}$ & $\mathbf{3}$ & $\mathbf{4}$ & $\mathbf{5 - 6}$ & $\mathbf{7 - 8}$ & $>\mathbf{8}$ \\
\hline $0.01-0.99$ & 59.2 & 25.1 & 11.5 & 3.7 & 0.4 & 0.0 & 0.0 \\
$1.00-1.99$ & 32.3 & 23.7 & 21.7 & 12.4 & 9.4 & 0.6 & 0.0 \\
$2.00-2.99$ & 21.4 & 17.0 & 19.2 & 18.3 & 18.3 & 4.8 & 0.9 \\
$3.00-4.99$ & 33.2 & 9.0 & 13.5 & 12.3 & 18.4 & 10.7 & 2.9 \\
$5.00-9.99$ & 31.0 & 7.0 & 6.3 & 10.6 & 19.7 & 15.5 & 9.9 \\
$10-100$ & 40.8 & 20.4 & 8.2 & 2.0 & 14.3 & 12.2 & 2.0 \\
\hline $\mathbf{2 0 1 3}$ & $\mathbf{1}$ & $\mathbf{2}$ & $\mathbf{3}$ & $\mathbf{4}$ & $\mathbf{5 - 6}$ & $\mathbf{7 - 8}$ & $>\mathbf{8}$ \\
$0.01-0.99$ & 65.6 & 23.5 & 8.1 & 2.4 & 0.4 & 0.0 & 0.0 \\
$1.00-1.99$ & 30.6 & 26.9 & 21.0 & 12.4 & 8.6 & 0.5 & 0.0 \\
$2.00-2.99$ & 25.7 & 17.4 & 13.2 & 18.8 & 22.2 & 2.4 & 0.3 \\
$3.00-4.99$ & 30.4 & 13.0 & 13.3 & 10.4 & 18.9 & 11.5 & 2.6 \\
$5.00-9.99$ & 23.0 & 13.6 & 3.7 & 6.3 & 15.7 & 24.6 & 13.1 \\
$10-100$ & 16.7 & 11.5 & 1.3 & 3.8 & 14.1 & 11.5 & 41.0 \\
\hline
\end{tabular}

Tab. 4. The number of different groups of non-citizen pupils at individual schools in 2005 and 2013 Source: Authors' calculations based on data from the Ministry of Education, Youth and Sport (Statistical Yearbook on Education - Performance Indicators 2005/2006 and 2013/2014

in the first row have just several (and often just one) noncitizen pupils in the student population, so it is almost impossible for there to be more than one immigrant group at the school; in the case of smaller schools, this applies to some extent also to the second and third rows.

Nevertheless, a basic statistical relation can be noticed in the table: the larger the share of non-citizen pupils at a school, the greater the number of different immigrant groups there tend to be at the school. In 2005, however, in $60 \%$ of schools where the share of non-citizen pupils exceeded one-tenth of all pupils, no more than two different migrant groups attended the school. This indicates that schools with non-citizen pupils from a large number of different backgrounds were rare (with some exception of schools with 5-8 groups). The figures from 2013 document the remarkable change: $41 \%$ of these schools had pupils from more than eight of the groups included in this study. This finding is even more interesting when we compare it to 2005 , when there were almost no such schools.

It would be interesting to know what kinds of schools fall into this category. The data 'speak clearly' on this: 56 out of 65 of these schools are in Prague and they are all large; they have at least 160 pupils and 53 of them have more than 300 pupils. The changes are evidently a direct consequence of the ongoing process of spatial concentration of non-citizen pupils that was mentioned in the first part of this section. Immigrants from all immigrant groups are concentrated primarily in Prague, but unlike in many big Western cities the different groups in Prague are not centred in specific parts of the city, and further evidence of this is that the schools with large shares of immigrants are located in various areas around the city. Logically, then, the noncitizen pupils at schools with large shares of immigrants will come from various different backgrounds. This situation is something entirely new, however, as in 2005 very few schools were in this situation and just a small number of groups tended to dominate the non-citizen population at a school; schools were thus more 'specialised' in teaching specific groups than they are today.

\subsection{The concentration of non-citizen pupils at schools: case studies}

The analysis described above revealed the main trends in the concentration of non-citizen pupils at schools, but the reliability of these findings needs to be tested by a change in scale, and this we shall do in the case studies of selected towns (Říčany, Mladá Boleslav, Karlovy Vary, Teplice, Tachov) and two boroughs in Prague (Prague 13 and 14), where a total of 77 schools are located.

For this study, we favoured mid-sized towns in order to minimise the role of the distance to a school on school choice and so that there would be both a sufficient number of schools within the unit of study and a sufficient number of non-citizen pupils. Therefore, the selection was limited to areas with a relatively large share of immigrants in which parents could freely choose between schools and where 'Tiebout sorting' could also be easily possible. Another criterion was the attempt to select towns with different socio-economic conditions in various parts of Bohemia. No Moravian towns were included in the study, as the only towns with a sufficient number of resident immigrants are Brno, which is too large for the study, and Český Těšín, where the situation is 'distorted' by its location on the Polish border.

Studies were carried out in the boroughs of Prague 13 Stodůlky, Jinonice, Třebonice, Řeporyje) and Prague 14 (Hloubětín, Kyje, Černý Most, Hostavice), two boroughs with the largest shares of non-citizen pupils among their resident populations. The high share of non-citizen pupils $(11.6 \%$ and $8.2 \%$ of the local student population, respectively) is an advantage for the analysis of the boroughs in Prague. A disadvantage, however, is that within a city it is no problem for parents to exercise their right to choose their children's school. Consequently, pupils living in one borough may easily attend school in another one. Unlike the towns, where the right to choose a school is limited by geographical constraints and additional commuting costs, the boroughs of Prague are not self-contained units in this respect. It is therefore difficult to capture those pupils who live in the boroughs analysed but study elsewhere. 
We analysed trends in the number of both Czech and noncitizen pupils at all schools in these selected cases, but due to limited space we can only present the main findings.

The first case study was in Ríčany, a rapidly growing town in the immediate suburban area of Prague. The town's growth is also apparent in the increasing number of schools in recent years and the increasing number of non-citizen pupils attending them. Almost all of them are concentrated in the three large schools, while among the six smallest schools there is only one non-citizen pupil. Immigrants seem therefore to prefer to send their children to large schools where there is a more anonymous environment and which also have some experience with non-citizen pupils. At none of the three large schools is there any substantial concentration of such pupils. The question is whether the findings for Ríčany are not distorted by the fact that the town is located within commuting distance of Prague, so some parents may instead choose to send their children to a school in Prague.

Another town included in the study was Mladá Boleslav, one of the most prosperous towns in the Czech Republic, and the location of the biggest car plant in the country. The abundance of job opportunities has attracted many new immigrants and this is reflected in the number of noncitizen pupils enrolled in local schools. They are very evenly distributed across schools in Mladá Boleslav, even when looked at by country of origin. There is only one exception, where the total number of pupils fell almost by half in the eight-year period, while the number of non-citizen pupils (and hence also their concentration at this school) increased significantly. A closer look at the data shows that most of them are of Slovak background (40 pupils).

A very different situation exists in the town of Karlovy Vary, which is well known for a higher concentration of immigrants (especially from Russia and other PostSoviet countries). Although their number did not change significantly during the period under observation, due to decreasing number of native pupils the share of noncitizen pupils increased. In 2005 the largest share of noncitizen pupils (29\%), two-thirds of whom were of Russian background, were enrolled at one small school, which was later closed. At present, most non-citizen pupils are enrolled at two schools which in 2005 had stood out as having a large share of them, but during the eight-year period the shares at these schools continued to increase while they tended to stagnate at the others.

A closer look at the data shows that the situation developed quite differently at each school. The first of them was the largest one in the city (610 pupils) and it had long tended to have a concentration of pupils from post-Soviet countries (including Russia and Ukraine). While the share of noncitizen pupils is on the rise here, the total number of pupils sharply decreased to only 358 pupils in 2013, which may be a sign of the process referred to in the literature above (e.g. Kostelecká et al., 2013), where a large share of noncitizen pupils at a school may lead parents not to enrol their children in that school. This practice has been described in various studies outside the Czech Republic (e.g. Lankford and Wyckoff, 2001; Söderström and Uusitalo, 2005).

The situation at the second school was different as the number of Czech students barely changed and the share of non-citizen pupils grew very slightly. In 2005 almost all the non-citizen pupils there were of Vietnamese background, but between 2005 and 2013 there was a significant decrease in the number of Vietnamese in the town, which had an impact on this school, but it then attracted non-citizen pupils from other backgrounds, in most cases Russia and Ukraine.

The town of Teplice also witnessed a substantial increase in the share of non-citizen pupils. This increase was very unevenly distributed among the schools in the town and the largest share of non-citizen pupils in Teplice was observed at two middle-sized schools in 2005. Both schools then experienced the biggest relative decrease in the number of Czech pupils in the town, so the share of non-citizen pupils increased further. As in the case of Karlovy Vary, our data for Teplice again signal that when the number of noncitizen children at a school is high Czech parents are less willing to send their children there.

Another town in the study, Tachov, occupied a very peripheral location geographically in the socialist period, but this has changed since the Western borders were opened. There are three main non-citizen groups here: Vietnamese, Ukrainians and Slovaks. While the number of pupils from the first two groups has decreased over time, the number of Slovaks has increased. In 2005 there was only a small share of non-citizen pupils at the two largest schools in the town, but the majority of them were attending one medium-size school, while at the two largest schools there were much smaller shares of noncitizen pupils. This suggested the possible segregation of minorities at one school, but this situation changed over the years, and although the above-mentioned medium-size school was still the school with the largest share of noncitizen pupils in 2013, their share had decreased and its composition had changed by then. Now Slovaks make up the majority of non-citizen pupils, while there are just a few pupils from Ukraine and Vietnam.

Finally, we look at the situation in the two boroughs of Prague: Prague 13 and Prague 14. Both of them witnessed a substantial increase in the share of immigrants among the pupil population, which doubled between 2005 and 2013, an increase that occurred at all schools in the boroughs but one. By contrast, the number of Czech pupils decreased in the majority of schools and despite the influx of noncitizen pupils, the overall numbers of pupils at schools in these boroughs also decreased. This can be partly explained by the fact that in both boroughs the population aged 5-14 declined by $10 \%$. The population trends in these boroughs are different from the trends in Prague in general, where the 5-14 age group is growing quickly, even though the total population and the number of non-citizens are growing at a slower pace. The decreasing number of pupils at the schools, in Prague 13 at least, is not then due to the fact that parents are sending their children elsewhere, but is the result of the overall decrease in the number of children living there, either because they are moving away or owing to low fertility. Now it is mainly immigrants (especially from post-Soviet countries) who are moving into these boroughs and most of them do not have children.

When we look at individual schools in Prague 13, a similar trend is apparent across most of them: as the number of non-citizen pupils rises in most cases, the number of Czech pupils decreases. There was a significant increase in the number of Czech pupils in just three schools; two of them had a very low share of non-citizen pupils. Similarly, all three schools with a growing number of Czech pupils in Prague 14 had below-average shares of non-citizen pupils. In both boroughs five schools had a large share of noncitizens; the number of Czech pupils almost did not change 
at two of them (one in each borough). The remaining three schools experienced a substantial drop of Czech pupils (one in Prague 13 and two in Prague 14).

The analysis of the situation at schools in the selected towns and two Prague boroughs revealed some shared trends, despite the specific contexts of the individual localities. We must remember that during the period of observation the number of non-citizen pupils was increasing, while conversely the number of native students was decreasing (Tab. 1). This decrease however was not uniform across all schools as the drop was generally much more apparent in the case of schools with a large share of non-citizen pupils. Even this tendency was not the rule, however, as we can see on the example of the schools in Karlovy Vary or Prague discussed above. Although schools with a large share of non-citizen pupils often experienced this development, others did not. This indicates that other factors prevent a possible outflow of Czech students when the number of non-citizen students rises.

The overall findings of the analysis are summed up on the left side of Table 5, which shows the correlation between an increase/decrease in the number of pupils at schools and the change in the share of non-citizen pupils attending the schools (schools without non-citizen pupils in 2005 or/and in 2013 were removed from the analysis). The figures clearly show that in every territorial unit except Tachov, where the situation was somewhat specific, there were larger decreases of number of pupils from schools where the share of noncitizen pupils was growing the fastest to schools where the number of immigrants had changed little. The level of the correlation was also low for the national level (last row), which, however, is not surprising: parents usually choose to send their children to a school within their territorial unit, so also these relations are valid just for the level of these units.

Admittedly, while this correlation may be a simplification and there may be other important factors that are not taken into account here (e.g. the size of the school: pupils tend most often to leave the largest schools, which is also where the largest numbers of non-citizen pupils are), the relatively high correlation coefficients and their relative consistency across the different environments in various territorial units, suggest that there is genuinely a tendency for Czech pupils to avoid schools where non-citizen pupils tend to enrol. But as a comparison of the Gini coefficients (calculated in the same manner as in section 3) in the next two columns in Table 5 shows, the overall level of concentration of noncitizen pupils at schools within most of the territorial units in the analysis did not increase significantly between 2005 and 2013. This is primarily due to increases in the numbers of non-citizen pupils at those schools where in 2005 there had been very few or none at all. While in 2005 non-citizen pupils accounted for less than $3 \%$ of pupils at $54 \%$ of schools, in 2013 it was only at $41 \%$ of schools. These proportions thus support the conclusions from Table 3 that the growing concentration of non-citizen pupils at schools that is shown in Figure 3 is more the result of the changing spatial distribution of immigrants than their concentration within relatively closed geographical units. This can be also confirmed by the fact that Gini coefficient for the Czech Republic as a whole (bottom row) is much higher than for each territorial unit. This is because this figure combines both concentrations between regions and within them. The Gini coefficients can also be used to compare the degree of concentration across individual territorial units. We can see that the highest concentration was observed in Karlovy Vary and Teplice, two towns in northwest Bohemia where we found some schools that had a large share of non-citizen pupils and simultaneously a decreasing number of native pupils.

\section{Conclusions}

This study of the regional distribution of non-citizen pupils at primary and lower secondary schools in the Czech Republic showed that during the period under observation, 2005 to 2013, the numbers of non-citizen pupils grew. Although most groups became more geographically dispersed, pupils from post-Soviet countries were an exception as a slight but stable increase in the spatial concentration of this group was observed during this period. Given that such students form the largest groups of noncitizens at schools, the effect of this process was to increase the spatial concentration of all non-citizen pupils generally in several regions, mainly in the metropolitan areas of Prague and Brno. The analysis of the data indicates that the spatial

\begin{tabular}{lccc}
\hline \multirow{2}{*}{ Town } & $\begin{array}{c}\text { Pearson correlation } \\
\text { coefficient }\end{array}$ & \multicolumn{2}{c}{ Gini coefficient of concentration } \\
\cline { 3 - 4 } & -0.948 & 2005 & 2013 \\
\hline Říčany & -0.512 & 0.219 & 0.381 \\
Mladá Boleslav & -0.584 & 0.419 & 0.292 \\
Karlovy Vary & -0.553 & 0.439 & 0.429 \\
Teplice & 0.556 & 0.388 & 0.419 \\
Tachov & -0.347 & 0.378 & 0.142 \\
Prague 13 & -0.654 & 0.328 & 0.350 \\
Prague 14 & -0.139 & 0.239 & 0.227 \\
Czech Republic & & 0.643 & 0.623 \\
\hline
\end{tabular}

Tab. 5: The relationship between the changing number of non-citizen pupils at a school and the total size of the school and the concentration trend.

Source: Authors' calculations based on data from the Ministry of Education, Youth and Sport (Statistical Yearbook on Education - Performance Indicators 2005/2006 and 2013/2014.

Note: The Pearson correlation coefficient indicates the relationship between the index of change in the total number of all pupils at the schools in the given territorial unit (number of pupils in 2013 divided by the number of pupils in 2005) and the change in the percentage of non-citizen pupils at these schools. The Gini coefficient indicates the degree of concentration of non-citizen pupils at schools in the given territorial unit; it is weighted by the size of schools 
behaviours of non-citizen pupils replicates that of the adult population, which has been described elsewhere in the Czech literature (Čermák and Janská, 2011; Drbohlav et al., 2010; Janská et al., 2014). This finding is logical because children in this age group usually follow their parents.

While the spatial behaviours of adult immigrants largely reflect their economic interests, the distribution of noncitizen pupils is the result of the combined effect of two key factors: the spatial distribution of immigrants in general, and the school choices of non-citizen and native parents. Experience outside the Czech Republic tells us that in many cases when parents have the option to choose their children's school this contributes to the ethnic and social segregation of pupils and leads to more ethnically homogeneous schools (e.g. Riedel et al., 2010). Some studies have even drawn attention to the fact that parents with higher socio-economic status try to assert their choice of school even in countries where there are restrictions on doing so.

As noted above, the Czech Republic is one of the countries where parents have the right to choose the school for their children that best conforms to their preferences, as long as there is sufficient capacity at the school, after pupils from the local district have enrolled. Given what we know from international studies about how school choice often reinforces the process of ethnic and social segregation, we had some concerns about whether an increasing share of non-citizens among pupils would lead to the segregation of non-citizen pupils at Czech schools. Nevertheless, this analysis showed that while there are signs of an increase in the concentration of non-citizen pupils at schools, the level of concentration is not yet alarming. The analysis also indicates that the increasing concentration in schools is likely due to the growing spatial concentration of noncitizens rather than to the fact that parents have options to choose schools.

This analysis has also confirmed that schools do not 'specialise' in one immigrant group - at schools with a larger share of non-citizen pupils they are always members of several different groups. This trend towards greater heterogeneity in schools moreover appears to have a strengthening tendency over time, and this is particularly true of large schools in Prague, which (unlike in 2005) are attended by numerous pupils from various backgrounds. This indicates that for the time being the Czech capital (unlike many Western metropolitan areas) is not witnessing any process of segregation of non-citizen pupils by origin into certain localities.

On the other hand, a closer look at the situation in the selected case study towns showed that in some cases developments in Czech schools resembles some trends described in the international literature. Schools with an increasing number or a large share of non-citizen pupils sometimes see this growth accompanied by a decrease in the total number of native pupils, as their parents withdraw them from these schools. It is not explicitly clear, however, at what percentage of non-citizen pupils at a school this withdrawal occurs. This phenomenon may occur in concert with many other factors, however, such as the size of the municipality in which the school is located, the availability and quality of other educational institutions within commuting distance, the quality of the school, and, last but not least, the origin and social composition of the school's students. To unequivocally confirm the assumption that the parents of native pupils withdraw their children from schools where there are large shares of non-citizen pupils, we would have to carry out other in-depth analyses (minimally with the parents, of course) that lie outside the scope of this article. This analysis of data on the distribution of non-citizen pupils at primary and lower secondary schools revealed that some trends witnessed in countries with long histories of migration are not yet in evidence in the Czech Republic. There is not a noticeable trend in Czech urban areas or schools towards the concentration or segregation of non-citizens or to the emergence of large ethnic neighbourhoods or schools with a majority of non-citizen pupils. It is possible that if preventive measures aimed at supporting the integration of migrants are not introduced, in time the developments in the Czech Republic could mimic the migration experiences of Western countries with all the same risks, but just with a slight delay (Čermák and Janská, 2011; Drbohlav, 2011). It is possible that some reasons why there is relatively little concentration or segregation of migrants, are the Czech Republic's brief experience of migration to the present, as well as the still lower immigration rates than those observed in Western Europe.

\section{Acknowledgement}

This article was written with the support of the Czech Science Foundation: "Integration of the children of nonnationals from the Czech lower secondary schools", registration number: 13-32373S.

\section{References:}

ALBA, R., NEE, V. (2005): Remaking the American mainstream: assimilation and contemporary immigration. Cambridge, Harvard University Press.

BIFULCO, R., LADD, H. F. (2007): School choice, racial segregation, and test-score gaps: Evidence from North Carolina's charter school program. Journal of Policy Analysis and Management, 26: 31-56.

BIFULCO, R., LADD, H. F., ROSS, S. L. (2009): Public school choice and integration evidence from Durham, North Carolina. Social Science Research, 38(1): 71-85.

BLACK, S. E. (1999): Do Better Schools Matter? Parental Valuation of Elementary Education. The Quarterly Journal of Economics, 114(2): 577-599.

BOURDIEU, P. (1983): Ökonomisches Kapital, kulturelles Kapital, soziales Kapital. In: Kreckel, R. [ed.]: Soziale Ungleichheiten (Sonderband 2; pp. 183-198). Göttingen, Schwartz.

BRAUN, R., BRAUNOVÁ, M., BRUMMER, M., DOVEC, O., HOZÁKOVÁ, V. (2015): The Position of StudentsForeigners in Czech Primary Schools. Procedia - Social and Behavioral Sciences, 186: 1122-1129.

BURGESS, S., BRIGGS, A. (2006): School assignment, school choice and social mobility. CMPO Working Paper, 06/157. Bristol, University of Bristol.

CEBOLLA-BOADO, H., GARRIDO MEDINA, L. (2011): The Impact of Immigrant Concentration in Spanish Schools: School, Class, and Composition Effects. European Sociological Review, 27(5): 606-623.

COLEMAN, D., SCHERBOV, S. (2005): Immigration and ethnic change in low-fertility countries - towards a new demographic transition? Paper presented to Population Association of America Annual Meeting, Philadelphia. 
ČERMÁK, Z., JANSKÁ, E. (2011): Rozmístění a migrace cizinců jako součást sociálněgeografické diferenciace Česka. Geografie-Sborník České geografické společnosti, 116(4): 422-439.

ČSÚ (2008): Život cizinců v ČR 2008. Praha, Český statistický úřad

ČSÚ (2012a): Pohyb obyvatelstva v Českých zemích 1785-2011, absolutní údaje. Praha, Český statistický úřad. [online] [cit. 01.10.2015]. Available at: https://www.czso.cz/csu/czso/ obyvatelstvo_hu

ČSÚ (2012b): Narození cizinci v ČR podle státního občanství - vývoj v letech 1995-2012, Demografická ročenka ČR 2008, 2009, 2010, 2011, 2012). Praha, Český statistický úr̆ad.

ČSÚ (2014a): Cizinci podle pohlaví a věku k 31. 12. 2014. Praha, Český statistický úřad.

ČSÚ (2014b): Věkové složení obyvatel k 1. 1. 2014. Praha, Český statistický úřad.

ČSÚ (2015a): R03 Trvale a dlouhodobě usazení cizinci v ČR 1985-2015 (31. 12.). Praha, Český statistický úřad.

ČSÚ (2015b): R04 Cizinci v ČR podle státního občanství 1994-2015 (31. 12.). Praha, Český statistický úřad.

ČSÚ (2015c): Školy a školská zařízení v České republice. Školní rok 2014/2015. Praha, Český statistický úřad.

DRBOHLAV, D., DZÚROVÁ, D., ČERNÍK, J. (2007): Integrace cizinců, žáků základních a středních škol, do české společnosti: Př́́klad Prahy. Geografie - Sborník České geografické společnosti, 112(2): 161-184.

DRBOHLAV, D., UHEREK, Z. (2007): Reflexe migračních teorií. Geografie - Sborník České geografické společnosti, 112(2): 125-141.

DRBOHLAV, D., MEDOVÁ, L., ČERMÁK, Z., JANSKÁ, E., ČERMÁKOVÁ, D., DZÚROVÁ, D. (2010): Migrace a (i) migranti v Česku. Kdo jsme, odkud přicházíme, kam jdeme. Praha, Sociologické nakladatelství.

DRBOHLAV, D. (2011): Imigrace a integrace cizinců v Česku: Několik zastavení na cestě země v její migrační proměně z Davida na téměř Goliáše. Geografie, 116(4): 401-421.

DURLAUF, S. N. (2005): Racial Profiling as a Public Policy Question: Efficiency, Equity, and Ambiguity. American Economic Review, 95(2): 132-136.

FONER, N., ALBA, R. (2008): Immigrant Religion in the U.S. and Western Europe: Bridge or Barrier to Inclusion? International Migration Review, 42(2): 360-392.

GALSTER, G. C. (2012): The Mechanism(s) of Neighbourhood Effects: Theory, Evidence, and Policy Implications. Neighbourhood Effects Research: New Perspectives. Dordrecht, Springer Netherlands.

GORARD, S. (2009): Does the index of segregation matter? The composition of secondary schools in England since 1996. British Educational Research Journal, 35(4): 639-652.

HÁJKOVÁ, E. (2015): Jazyková výchova dětí s odlišným mateřským jazykem $\mathrm{v}$ české mateřské škole. Praha: Univerzita Karlova v Praze, Pedagogická fakulta.

HÁJKOVÁ, E. (2014): Žák-cizinec v hodinách češtiny na základní škole. Praha: Univerzita Karlova v Praze, Pedagogická fakulta.
HASMAN, J. (2014): Prostorové chování imigrantů: analýza prostorové příbuznosti migračních skupin. Disertační práce. Praha, Katedra sociální geografie a regionálního rozvoje PřF UK.

HASTINGS，J. S., KANE，T. J., STAIGER，D. O. (2006): Preferences and heterogeneous treatment effects in a public school choice lottery. (No. w12145). Cambridge, National Bureau of Economic Research.

ICELAND, J. (2014): Residential Segregation: A Transatlantic Analysis. Washington, D.C., Migration Policy Institute.

JANČǍ̌íK, A., KOSTELECKÁ, Y. (2015): The Scoring of Matching Questions Tests: A Closer Look. The Electronic Journal of e-Learning, 13(4): 270-276.

JANSKÁ E. (2007): Adaptace/integrace imigrantů do majoritní společnosti: druhá generace cizinců a jejich rodičů v Česku. Geografie - Sborník České geografické společnosti, 112(2): 142-160.

JANSKÁ, E., ČERMÁK, Z., WRIGHT, R. (2014): New immigrant destinations in a new country of immigration: settlement patterns of non-natives in the Czech Republic. Population Space and Place, 20(8): 680-693.

JOHNSTON, R., BURGESS, S., HARRIS, R., WILSON, D. (2008): 'Sleep-walking towards segregation'? The changing ethnic composition of English schools, 1997-2003: an entry cohort analysis. Transactions of the Institute of British Geographers, 33(1): 73-90.

KOSTELECKÁ, Y., JANČǍ̌ÍK, A. (2014): The Process of Czech Language Acquisition by Foreign Pupils at Lower Secondary School. Journal on Efficiency and Responsibility in Education and Science, 7(1): 7-13.

KOSTELECKÁ, Y., KOSTELECKÝ, T., KOHNOVÁ, J., TOMÁŠOVÁ, M., POKORNÁ, K., VOJTÍŠKOVÁ, K., ŠIMON, M. (2013): Žáci-cizinci v základních školách: Fakta, analýzy, diagnostika. Praha, Univerzita Karlova v Praze, Pedagogická fakulta.

KOSTELECKÁ, Y., KOSTELECKÝ T., JANČǍ̌́IK, A., KOHNOVÁ, J. (2015): Děti imigrantů v českých školách. Speciální pedagogika, 25(1): 29-51.

KOSTELECKÝ, T., PATOČKOVÁ, V., ILLNER, M. (2012): Problémové rezidenční čtvrti a politiky k jejich regeneraci v postsocialistickém městě - studie Prahy. Praha, Sociologický časopis, 48(1): 39-63.

LACHMANOVÁ, L. (2007): Vývoj a úspěšnost modelů integrace imigrantů (na př́kladu Rakouska, Francie a Nizozemska). Geografie - Sborník České geografické společnosti, 112(2): 221-236.

LANKFORD, H., WYCKOFF, J. (2001): Who would be left behind by enhanced private school choice. Journal of Urban Economics , 50: 288-312.

MASSEY, D. S. (2008): New faces in new places: the changing geography of American immigration. New York, Russell Sage Foundation.

NETRDOVÁ, P., NOSEK, V. (2009): Přístupy k měření významu geografického rozměru společenských nerovnoměrností. Geografie - Sborník České geografické společnosti, 114(1): 52-65.

NOVOTNÝ, J. (2007): On the measurement of regional inequality: does spatial dimension of income inequality matter? The Annals of Regional Science, 41(3): 563-580. 
NOVOTNÝ, J., JANSKÁ, E., ČERMÁKOVÁ, D. (2007): Rozmístění cizinců v Česku a jeho podmiňující faktory: pokus o kvalitativní analýzu. Geografie, 112(2): 204-220.

NOVOTNÝ, J., NOSEK, V., JELÍNEK, K. (2014): EasyStat. Praha, Př́rodovědecká fakulta UK. [online] [cit. 01.10.2015]. Available at: http://web.natur.cuni. $\mathrm{cz} / \sim$ pepino/EasyStat.zip

OPDENAKKER, M.-C., VAN DAMME, J. (2001): Relationship between School Composition and Characteristics of School Process and their Effect on Mathematics Achievement. British Educational Research Journal, 27(4): 407-432.

PAPOUŠKOVÁ, R. (2007): Migrace za studiem: Cizinci na Vysoké škole ekonomické v Praze. Geografie - Sborník České geografické společnosti, 112(2): 185-203.

PEDRAJA-CHAPARRO, F., SANTÍN, D., SIMANCAS, R. (2016): The impact of immigrant concentration in schools on grade retention in Spain: a difference-in-differences approach. Applied Economics, 48(21): 1978-1990

PORTES, A., FERNÁNDEZ-KELLY, P., HALLER, W. (2005): Segmented assimilation on the ground: The new second generation in early adulthood. Ethnic and Racial Studies, 28(6): 1000-1040.

RIEDEL, A., SCHNEIDER, K., SCHUCHART, C., WEISHAUPT, H. (2010): School Choice in German Primary Schools: How Binding are School Districts? Journal for Educational Research Online, 2(1): 94-110.

RUOFF, G. (2006): Segregation in the Classroom: An Empirical Test of the Schelling Model. Rationality and Society, 18(1): 95-117.

SCHNEEWEIS, N. (2011): Educational institutions and the integration of migrants. Journal of Population Economics, 24(4): 1281-1308.

SCHNEEWEIS, N. (2013): Immigrant Concentration in Schools: Consequences for Native and Migrant Students. Discussion papers No. 7230. Bonn, Institute for the Study of Labor (IZA).

SCHNEEWEIS, N. (2015): Immigrant concentration in schools: Consequences for native and migrant students. Labour Economics, 35: 63-76.

SÖDERSTRÖM, M., UUSITALO, R. (2005): School choice and segregation: evidence from an admission reform. Working paper 2005:7. Uppsala, Institute for Labour Market Policy Evaluation (IFAU).
Statistical Yearbook on Education - Performance Indicators 2005/2006, 2007/2008, 2009/2010, 2011/2012, 2013/14

THRUPP, M., LUPTON, R. (2006): Taking school contexts more seriously: The social justice challenge. British Journal of Educational Studies, 54(3): 308-328.

UN (2013): International Migration Report 2013: Migrant Well-being and Development. [online] [cit. 01.10.2015]. Avaiable at: http://www.un.org/en/development/ desa/population/publications/migration/migrationreport-2013.shtml

URQUIOLA, M. (2005): Does School Choice Lead to Sorting? Evidence from Tiebout Variation. American Economic Review, 95(4): 1310-1326.

VODIČKOVÁ, K., KOSTELECKÁ, Y. (2014): Diagnostic Tests in Czech for the Children of Immigrants Attending Primary Schools. e-Pedagogium, (4): 38-51.

VODIČKOVÁ, K., KOSTELECKÁ, Y. (2016): Diagnostic Tests in Czech for Pupils with a First Language Different from the Language of Schooling. Center for Educational Policy Studies Journal, 6(1): 31-48.

VOJTKOVÁ, M. (2007): Demografické události cizinců v ČR. Socioweb [online], (12) [cit. 2013-0106]. Available at: http://www.socioweb.cz/index. php?disp $=$ temata\&shw $=292 \& l s t=119$

VAN HAM, M., MANLEY, D. (2012a): Segregation, Choice Based Letting and Social Housing: How Housing Policy Can Affect the Segregation Process. Discussion Paper Series (IZA DP No. 6372). Bonn, Institute for the Study of Labor (IZA).

VAN HAM, M., MANLEY, D. (2012b): Neighbourhood Effects Research at a Crossroads: Ten Challenges for Future Research. Environment and Planning A, 44(12): 2787-2793.

VAN HAM, M. MANLEY, D. (2013): Occupational Mobility and Living in Deprived Neighbourhoods: Housing Tenure Differences in Neighbourhood Effects. Discussion Paper Series (IZA DP No. 7815). Bonn, Institute for the Study of Labor (IZA).

ZHOU, M., CAI, G. (2008): Trapped in Neglected Corners of a Booming Metropolis: Residential Patterns and Marginalization of Migrant Workers in Guangzhou. Urban China in Transition. Oxford, UK, Blackwell Publishing.

\section{Please cite this article as:}

HASMAN, J., KOSTELECKÁ, Y., HÁNA, D. (2016): The spatial concentration of immigrant pupils at primary and lower secondary schools in the Czech Republic. Moravian Geographical Reports, 24(4): 38-51. Doi: 10.1515/mgr-2016-0021. 